\title{
Characterization of physical properties of two isoforms of translation elongation factor $1 \mathrm{~A}$
}

\author{
A. V. Novosylna, A. A. Timchenko, E. I .Tiktopulo, I. N. Serdyuk, B. S. Negrutskii,A. \\ V. El'skaya
}

Institute of molecular biology and genetics NAS of Ukraine

Academicain Zabolotnog str., 150, Kyiv, 03680 Ukraine

${ }^{1}$ Institute for protein research RAS

Institutskaya Str, 4, Puschino, 142290, Russia

aleksnova@yahoo.com

\begin{abstract}
Two tissue-specific isoforms of mammalian translation elongation factor $1 \mathrm{~A}$, eEF1A1 and eEF1A2, are 98\% similar. However, some of their functions in the organism are different which in some cases could lead to the induction of carcinogenesis. We supposed that slight difference of primary sequences may cause significant differences of spatial structures of eEF1A isoforms affecting, in its turn, the ability of one or another isoform to interact with protein partners. The differential scanning microcalorimetry and circular dichroism in "near" and "far" UV regions were used to determine that potentially oncogenic eEF1A2 isoform possesses a more compact spatial organization than eEF1A1, and the differences are revealed at the levels of both secondary and tertiary structure of proteins.
\end{abstract}

Keywords: translation elongation factor eEF1A1, protein biosynthesis, differential scanning microcalorimetry, circular dichroism

Introduction. eEF1A is believed to be a multifunctional protein, the canonical functions of which are to promote efficient binding of aminoacyl-tRNA to $80 \mathrm{~S}$ ribosome and to provide correct codon-anticodon interaction in ribosomal A site [1]. Two tissue-specific isoforms of eEF1A have been identified, namely, eEF1A2, expressed only in neural and muscular tissues, and eEF1A1, discovered in all the other tissues $[2,3]$. The reason of two isoforms presence is not yet understood. The appearance of eEF1A2 in non-specific tissue has been found to relate to the induction of carcinogenesis [4-8]. It remains unknown in what way eEF1A2, $98 \%$ similar to eEF1A1, which is specific for this kind of tissue, may

(C) A. V. NOVOSYLNA, A. A. TIMCHENKO, E. I .TIKTOPULO, I. N. SERDYUK, B. S. NEGRUTSKII,A. V. EL'SKAYA, 2007 be related to the formation of tumours in the latter. We supposed that even slight aminoacid substitutions in eEF1A2 are capable of causing some divergence in spatial structures of this protein globule, which may result in the modification of its known functions and appearance of some new ones. To check our assumption we have performed the comparative analysis of molecular dynamics of both isoforms, and found out the possibility of differences in the secondary structure and dynamics of these protein globules $[9,10]$. Current work presents experimental data on the comparison of eEF1A1 and eEF1A2 using differential scanning microcalorimetry and circular dichroism (CD) in "near" and "far" UV regions.

Materials and Methods. Isolation and characterization of eEF1A. eEF1A1 was isolated from 


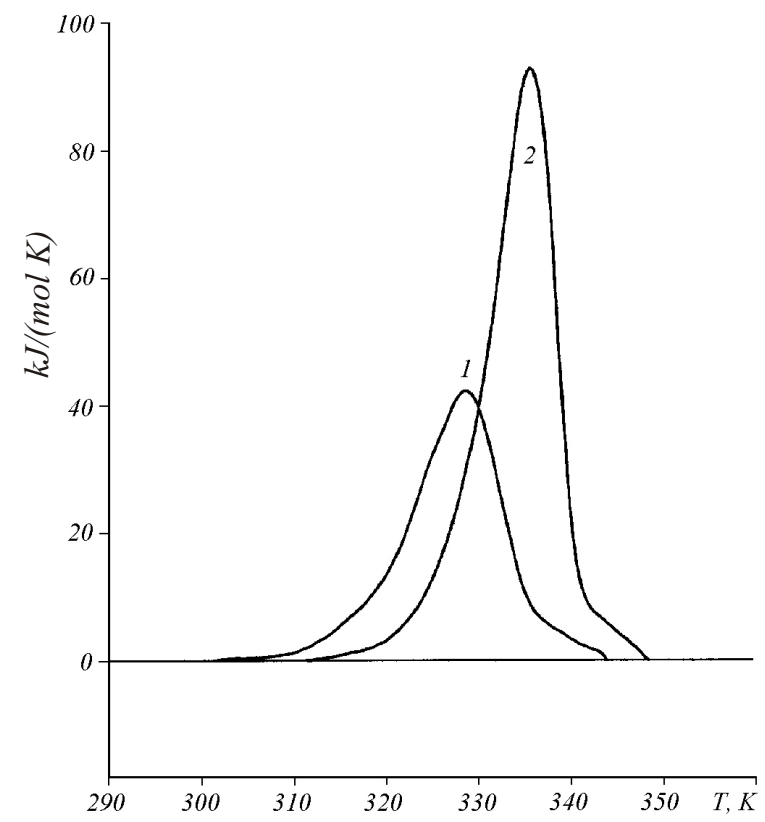

Fig.1 Temperature dependence of excessive heat capacity for eEF1A in $30 \mathrm{mM}$ tris- $\mathrm{HCl}$, pH 7.5, containing $20 \%$ glycerol, $6 \mathrm{mM}$ B-mercaptoethanol, $1 \mathrm{mM} \mathrm{MgCl}$, and $150 \mathrm{mM} \mathrm{KCl:1} \mathrm{-} \mathrm{melting}$ curve of eEF1A1;2 - melting curve of eEF1A2

rabbit liver using the combination of ion-exchange chromatography and gel-filtration, as described in [11], with slight modifications.

eEF1A2 was isolated from rabbit muscles using the same scheme, but for the first stage of purification chromatography on Sephacril S-400, which did not effect the preparation purity.

The activity of eEF1A was determined in the reaction of GDP $/\left[{ }^{3} \mathrm{H}\right] \mathrm{GDP}$ exchange [12].

Differential scanning microcalorimetry. Calorimetric measurements were conducted in precision scanning microcalorimeter SCAL-1 (SCAL Co. Ltd., Pushchino, Russia) in glass cells $(0.3 \mathrm{ml})$ with the rate of $1.0 \mathrm{~K}$ per $1 \mathrm{~min}$ under excessive pressure of two atmospheres [13]. The dialysis of all protein samples against corresponding buffer was conducted before measurements. Concentrations of proteins used were in the range of $2.3-2.5 \mathrm{mg} / \mathrm{ml}$. Thermodynamic analysis of the profile of the excess of heat capacity was carried out according to [14].

$C D$ in "far" and "near" UV regions. The secondary structure of proteins was investigated by CD spectroscopy using spectropolarimeter JASCO-600
(Japan) at wavelengths of 190-250 nm ("far" UV range) and 250-310 nm ("near" UV range). Molar ellipticity was calculated using the following equation:

$$
[\theta]=[\theta]_{\exp } M_{r e s} /(L C),
$$

where $C$ - concentration of protein $(\mathrm{mg} / \mathrm{ml}), L-$ optical path length of cuvette $(\mathrm{mm}),[\theta]_{\exp }$ - measured ellipticity (degrees) and $M_{\text {res }}$ - mean molecular mass of peptide residue $(\mathrm{Da})$, calculated from its aminoacid sequence. Measurement of "far" UV was carried out in $0.1 \mathrm{~mm}$ cuvette, and measurement of near CD was conducted in $1 \mathrm{~mm}$ cuvette. Concentration of proteins was $1 \mathrm{mg} / \mathrm{ml}$.

Results and Discussion. Differential scanning microcalorimetry. Differential scanning microcalorimetry allows obtaining and comparing thermodynamic parameters, characteristic for heat-induced conformational changes of proteins $[14$, 15].

Computer analysis of molecular dynamics of eEF1A isoforms testified to the possibility of conformational changes in eEF1A1 molecule due to interdomain interactions, while eEF1A2 is specific for a more closed conformation $[9,10]$. Therefore, one can expect the comparison of the thermodynamic parameters of the two isoforms of eEF1A to be informative to reveal the difference in thermal stability and enthalpy of denaturation. Since the stability of protein molecule is associated with its structure, the analysis of thermodynamic characteristics of the isoforms may evidence either to structural similarity or difference in their structures, and characterize relative compactness of these proteins.

Temperature dependences of the excessive partial heat capacity are presented in Fig. 1. Almost two-fold difference of denaturation heat of two isoforms is observed. For eEF1A1 $\Delta \mathrm{H}_{\text {total }}$ is $580.0 \mathrm{Kj} \backslash \mathrm{mol}$, while for eEF1A2 $\Delta \mathrm{H}_{\text {total }}$ is $910.0 \mathrm{Kj} / \mathrm{mol}$. Comparison of the melting curves also shows that melting of the eEF1A1 molecule starts earlier than that of eEF1A2. The maxima of transition are $55.5^{\circ} \mathrm{C}$ for eEF1A 1 and $62.7^{\circ} \mathrm{C}$ for eEF1A2. Half-width temperature of the transition $(\Delta T)$ equals $11.0^{\circ} \mathrm{C}$ for eEF1A1, and $8.1^{\circ} \mathrm{C}$ for eEF1A2. Thus, eEF1A isoforms possess different spatial structure. Significant increase in enthalpy of denaturation 


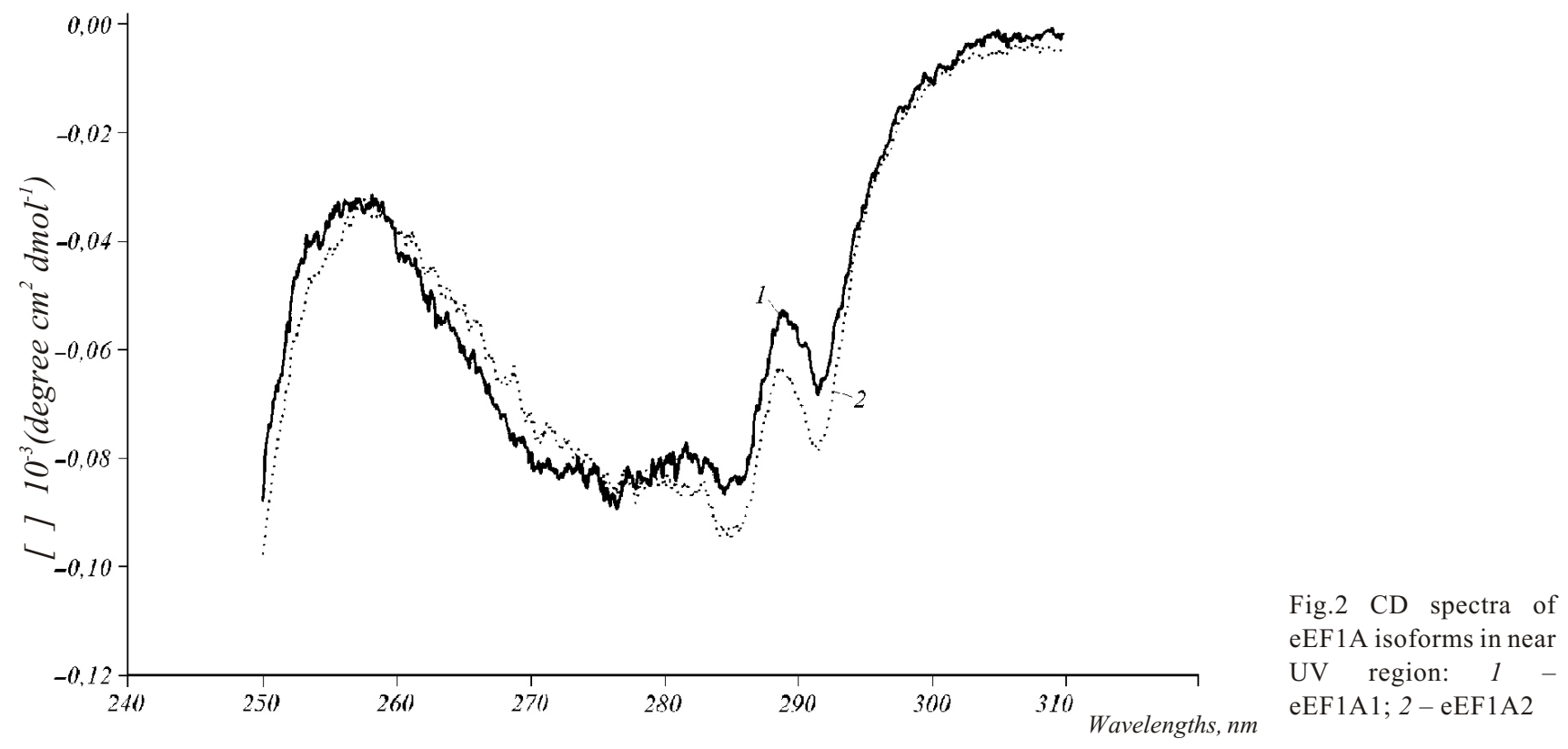

and decrease in half-width transition at eEF1A2 melting testify to a more compact conformation of eEF1A2, which has been earlier assumed using the data of molecular dynamics $[9,10]$.

"Near" UV CD. CD spectrum in near UV region (250-350 nm), presenting signals of such chromophores as aromatic amino acids and disulphide bonds, may provide useful information about the tertiary structure of a protein.

Signals in 250-270 $\mathrm{nm}$ region are specific for phenylalanine residues, $270-290 \mathrm{~nm}$ region - for tyrosine, and the ones in $280-300 \mathrm{~nm}$ region are inherent to tryptophan. Disulphide bonds provide weak signals along the entire near UV spectrum [16, 17].

Taking into account that both eEF1A1 and eEF1A2 are $98 \%$ similar, have the same positions in the primary structures, and contain almost equal amount of aromatic amino acids (there is only one substitution of Phe for Ser in eEF1A2; overall amount of amino acids in eEF1A1 (eEF1A2) is Trp - 5(5), Tyr - 12(12), Phe $-14(13))$, the mentioned method could be useful to test the identity or difference of tertiary structures of the isoforms.

Near UV CD spectra of eEF1A1 and eEF1A2 are shown in Fig.2. The difference in CD signals was observed in the entire spectrum of near UV region. We could not exclude the fact that alterations in the Phe-spe- cific region of $\mathrm{CD}$ spectrum might result partially from the difference in $393^{\text {rd }}$ position of primary structures of the isoforms (Phe393 in eEF1A1 or Ser393 substitution in eEF1A2). However, the difference in the rest of the spectrum is the direct consequence of changes in the tertiary structure of these proteins. Therefore, the data of near UV CD testify in favour of evident differences in tertiary structures of the isoforms.

"Far" UV CD. It proved to be important to determine whether local differences of spatial structures of eEF1A isoforms are accompanied by changes in the secondary structure of these proteins. The latter can be investigated using $C D$ spectroscopy in far UV region (190-250 nm). Peptide bonds become chromophores at these wavelengths, and signal appears if the bonds are in regularly folded surrounding. The specific form and size of $\mathrm{CD}$ spectrum are mainly conditioned by $\alpha$-helical structures in protein molecule [18].

Far UV CD spectra of eEF1A1 and eEF1A2 are shown in Fig.3. The increase in the molar ellipticity peak at $210 \mathrm{~nm}$ was observed for eEF1A2 as compared to eEF1A1. Since this wavelength is specific for $\alpha$-helical structures, the increment of CD signal evidences to partial loss of $\alpha$-helical structures in the secondary structure of eEF1A2. These data correlate with the results of our molecular dynamics simulation on partial unwinding of $\alpha$-helix Lys36-Glu48 of eEF1A2 $[9,10]$. 


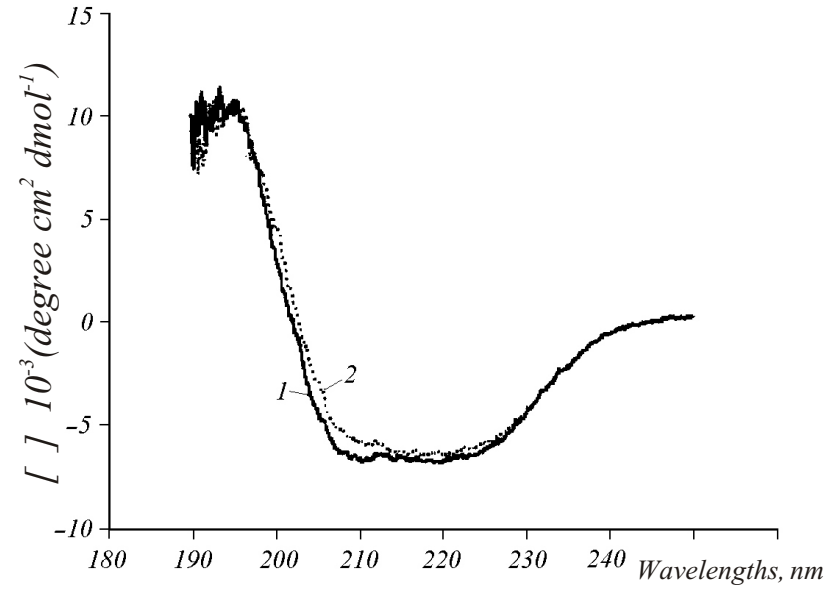

Fig. 3 CD spectra of eEF1A isoforms in far UV region: 1 - eEF1A1; 2 - eEF1A2

Therefore, the comparative analysis of spatial structures of two tissue-specific eEF1A isoforms, using biophysical methods, has been carried out for the first time. One of the isoforms is involved in ovarian cancer and cancer of lungs in humans $[4,5,7,8]$. The structure of eEF1A2 has been shown as more compact and characterized by partial unwinding of $\alpha$-helix Lys36-Glu48. Some differences have been also discovered in the tertiary structures of protein isoforms. These specificities of spatial organization may result in the exposure of functional sites in eEF1A2, capable of binding signal molecules, which may serve as one of the reasons for oncogenicity of this isoform.

Current work is among the first studies, proving that $98 \%$ similar isoforms of homologous proteins may have different spatial conformations. Thus, not only the changes in the primary structure, revealed e.g. in the appearance of new domains, or in elimination or appearance of new sites of post-translational modifications, but also the changes in their spatial conformation are important for the functional divergence of the protein isoforms. These data will allow extending the direction of searching for multiple families of various isoproteins.

The authors are grateful to the Fund of fundamental researches of the Ministry of Science and Education of Ukraine, INTAS and Wellcome Trust for their financial support. The authors are also grateful to B. S. Melnyk for the measurements of CD spectra.
О. В. Новосильна, О. О. Тимченко, С. І. Тиктопуло, I. М. Сердюк, Б. С. Негруиький, Г. В. Сльська

Характеристика фізичних властивостей двох ізоформ фактора елонгації трансляції еEF1A

Резюме

Дві тканиноспецифічні ізоформи фактора елонгації 1 А ссавичів (еEF1A1 і еEF1A2) ідентичні на $98 \%$. Але деякі їхні функиії в організмі значно різняться, що в окремих випадках може бути пов'язано з індукиією канцерогенезу. Ми припустили, що незначна різниия у первинних послідовностях може призводити до суттєвих відмінностей у просторовій структурі ізоформ еEF1A. Це, в свою чергу, може впливати на здатність тієї чи іншої ізоформи взаємодіяти з білками-партнерами. В даній роботі методами диференційної сканувальної мікрокалориметрії $і$ кругового дихроїзму на ділянках далекого $і$ ближнього УФ встановлено, щзо потенційно онкогенна ізоформа еЕF1А2 має компактнішу просторову структуру, ніж еЕF1A1, причому відмінності проявляються на рівні як вторинної, так і третинної структури білків.

Ключові слова: фактор елонгації трансляції еЕF1A, біосинтез білка, дифференційна сканувальна мікрокалориметрія, круговий дихроїзм.

\section{REFERENCES}

1. Negrutskii B. S., Deutscher M. P. Channeling of aminoacyl-tRNA for protein synthesis in vivo // Proc. Nat. Acad. Sci. USA.-1991.-88.-P. 4991-4995.

2. Knudsen S. M., Frydenberg J., Clark B. F. C., Leffers $H$. Tissue-dependent variation in the expression of elongation factor-1 alpha isoforms: isolation and characterisation of a cDNA encoding a novel variant of human elongation-factor 1 alpha // Eur. J. Biochem.-1993.-215.-P. 549-554.

3. Lee S., Wolfraim L. A., Wang E. Differential expression of S1 and elongation factor-1 alpha during rat development // J. Biol. Chem.-1993.-268.-P. 24453-24459.

4. Lee J. M. The role of protein elongation factor eEF1A2 in ovarian cancer // Reprod. Biol. Endocrinol.-2003.-1.-P. 69.

5. Anand N., Murthy S., Amann G., Wernick M., Porter L. A., Cukier I. H., Collins C., Gray J. W., Diebold J., DemetrickD. $J$., Lee J. M. Protein elongation factor EEF1A2 is a putative oncogene in ovarian cancer // Nat. Genet.-2002.-31.P. 301-305.

6. Tomlinson V. A., Newbery H. J., Wray N. R., Jackson J., Larionov A., Miller W. R., Dixon J. M., Abbott C. M. Translation elongation factor eEF1A2 is a potential oncoprotein that is overexpressed in two-thirds of breast tumours // BMC Cancer.-2005.-5.-P. 113.

7. Zhu H., Lam D. C., Han K. C., Tin V. P., Suen W. S., Wang E., Lam W. K., Cai W. W., Chung L. P., Wong M. P. High resolution analysis of genomic aberrations by metaphase and array comparative genomic hybridization identifies candidate tumour genes in lung cancer cell lines // Cancer Lett.-2007.-245.-P. 303-314.

8. Li R., Wang H., Bekele B. N., Yin Z., Caraway N. P., Katz R. L., Stass $S$. A., Jiang $F$. Identification of putative oncogenes in lung adenocarcinoma by a comprehensive functional genomic approach // Oncogene.-2006.-25.-P. 2628-2635.

9. Каніболоцький Д., Новосильна О., Негруцький Б., Міроиниченко М., Сльська Г. Вивчення конформаційної рухли- 
вості ізоформи еЕF1А2 фактора елонгації трансляції 1А людини // Вісн. нац. ун-ту імені Тараса Шевченка. Сер. біологія.-2007.-Вип. 49-50.-С. 12-15.

10. Каниболочкий Д. С., Новосильная А. В., Негруцкий Б. С., Ельская $A$. В. Конформационная подвижность фактора элонгации трансляции еEF1A1 человека // Біополімери і клітина.-2007.-23, № 4.-С. 307-317.

11. Shalak V. F., Budkevich T. V., Negrutskii B. S., El'skaya A. V. A fast and effective method for purification of elongation factor 1A from rabbit liver // Ukr. Biokhim. Zh.-1997.69.-P. 104-109.

12. Carvalho M. D., Carvalho J. F., Merrick W. C. Biological characterization of various forms of elongation factor 1 from rabbit reticulocytes // Arch. Biochem. and Biophys.1984.-234.-P. 603-611.

13. Senin A. A., Potekhin S. A., Tiktopulo E. I., Filomonov V. V. Differential Scanning Microcalorimeter SCAL-1 // J. Therm. Anal. Calorimetry.-2000.-62.-P. 153-160.

14. Privalov P. L., Potekhin S. A. Scanning microcalorimetry in studying temperature-induced changes in proteins // Meth. Enzymol.-1986.-131.-P. 4-51.
15. Sturtevant J. M. Heat capacity and entropy changes in processes involving proteins // Proc. Nat. Acad. Sci. USA.-1977.-74.-P. 2236-2240.

16. Gething M.-J., Davidson R. E. Chorismate mutase/prephenate dehydratase from Escherichia coli K12. Effect of phenylalanine, $\mathrm{NaCl}$ and $\mathrm{pH}$ on the protein conformation // Eur. J. Biochem.-1978.-86.-P. 159-164.

17. Plunkett G., Clarence A. Ryan reduction and carboxamidomethylation of the single disulfide bond of proteinase inhibitor I from potato tubers. Effects on stability, immunological properties, and inhibitory activities // J. Biol. Chem. 1980.-255.-P. 2752-2775.

18. Тиноко И., Зауэр К., Вэнг Д., Паглиси Д. Физическая химия. Принципы и применение в биологических науках // Техносфера.-2005.-P. 584-587.
UDC 577.217

Received 21.05.07 